\title{
Pioneer of cultural, post-colonial and social theory
}

\author{
Lisa Blackman ${ }^{1} \cdot$ Valerie Walkerdine ${ }^{2}$
}

Published online: 7 July 2020

(c) Springer Nature Limited 2020

This issue is dedicated to the work of Couze Venn, who was an important figure in social. cultural and post/decolonial theory until his death in 2019 aged 79. We had initially planned this volume to be a celebration of his work whilst he was still alive to be able to see it, but events overtook us. Couze was a huge inspiration and founding influence on the journal Subjectivity, introducing throughout the different periods of his writing a distinctive focus and attention on subjectivity, which he thought through the interconnected processes of affect, individuation and relationality. He was in dialogue with many thinkers, including the work of Bracha Ettinger, Gilbert Simondon, Bernard Steigler, and many others, always looking for the traces of what he came to identify as the "compossible".

The initial aim of the issue was to republish previously published papers by Couze, chosen by him as showing a range of his work on issues related to subjectivity over the years. In addition, Couze was contributing a new paper, his last and unfinished paper, 'Affective field and political subjectivities in the shadow of neofascism', in which he explores subjectivity and fascism in the light of the alt-right, new populisms and developments in global capital. In the notes in part two he also gestures to the role of what he calls 'teletechnology'. Given that we are writing this in the midst of a pandemic lockdown, having in. which governments have utilised the affects of fear and panic, as well as confusion and chaos, to create a compliant and quiesant global population, in the light of terminally depleted medical services, we should take his thoughts, written before this, very seriously. He never finished that paper but we publish the work as it was - a substantial draft of part one and notes towards part two. Couze was working on his second half notes right up until the last few days of his life, and was very keen to make sure his notebook notes could be found and passed to us. We reproduce them, cryptic as they are, in that spirit.

Lisa Blackman and Valerie Walkerdine have contributed equally to the work.

Lisa Blackman

coa011b@gold.ac.uk

1 Department of Media and Communications, Goldsmiths, University of London, New Cross, London SE14 6NW, UK

2 School of Social Sciences, Cardiff University, Cardiff CF10 3AT, UK 
Bracha Ettinger also undertook to provide a reply to and commentary on the paper and began that process in a wonderful presentation by video link at Goldsmiths last year. However, illness and overwork have taken their toll and so we will be publishing her paper in a later issue, with further tributes and commentaries on Couze's writing. Suffice it to say that Bracha began to engage in a profound way with the insights into fascism that Couze provided. Given that Couze was always thinking with Ettinger and was keen to receive feedback from his interlocutors, we look forward to being able to continue this important conversation in the months and years to come.

The issue also contains some wonderful tributes to the work of Couze across different fields and areas, provided by former colleagues and students. They also provide, for an audience less familiar with his work, key insights into specific works that have been important to them. The tributes are made by his dear friend and long term collaborator Julian Henriques, now a Professor in Cultural Studies at Goldsmiths, University of London, by his former $\mathrm{PhD}$ student and collaborator on the journal Theory, Culture \& Society, Simon Dawes, now a lecturer at l'Institut d'études culturelles et internationales (IECI), by his former student and long term friend, interlocutor and collaborator Jeremy Gilbert, now a Professor in Cultural Studies at the University of East London, by his long term friend and working class academic Diane Reay, Professor of Education at Cambridge University, by John Mason, a former student of Couze in the late ' 80 s, at the then East London Polytechnic, by his friend and former colleague in Cultural Studies at University of East London, Ashwani Sharma, now at the London College of Communication, and by Shela Sheikh, who worked with him in the former Centre for Cultural Studies at Goldsmiths, University of London, now a lecturer in cultural studies in the Department of Media, Communications and Cultural Studies at Goldsmiths, University of London. We have also included a wonderful tribute by Gargi Bhattacharyya, Professor in Sociology at the University of East London, writing as an "unknown reader", that is somebody who didn't know Couze personally, memorialising him instead through an astute and careful engagement with his book, The Postcolonial Challenge. It is true to say that there are many others who we know would pay and want to pay their own tributes, and would identify and find that unique mixture of friendship, collaboration and critical dialogue with his work that marked him out as a serious scholar, intellectual and kind, gentle and sensitive man.

Couze was born into a large Tamil family in Mauritius, growing up speaking French, English and Creole. He left Mauritius at 18 to study mathematics at St Andrews, but his attention soon turned to philosophy. He became part of the post-1968 British turn to French political and social theory, bringing French social theory into an Anglophone context and was key in establishing the journal Ideology \& Consciousness (later I and C), which largely introduced the work of Michael Foucault and Jacques Lacan into the UK, providing a deep understanding of French theory, relatively little known in the UK at that time. He developed this work in the jointly authored 'Changing the Subject: Psychology, Social Regulation and Subjectivity', (Henriques, Hollway, Urwin, Venn and Walkerdine) a landmark publication of 1984 that helped to shape the approach to critical work in psychology for many 
years. Couze always provided considerable erudition and was a source of inspiration to the other authors.

During the 1980's more black psychologists were entering the discipline and critiquing the assumptions about normative psychological health and wellbeing, which were based on a white, western, male subject. The inherent racism and ethnocentrism of psychology, and the disproportionate numbers of white psychologists, as opposed to black psychologists within a global context was a key concern. It is within this maelstrom of debate, and the diverse yet unified calls for changing the subject of psychology, that the collective authors of Changing the Subject's distinct interdisciplinary approach to psychological issues and subjectivity was to be consolidated and developed. The book was not necessarily on reading lists within psychology at the time, perhaps more likely to be encountered within social and cultural theory. It did take pride of place in an independent bookshop in Camden Compendium Books which Wikipedia reliably tells us "was for many years the main place for "the London literary avant-garde" [3]. It was a key venue for the British Poetry Revival [4] and for the availability of the texts of post-1968 political and cultural theory.

Couze continued his commitment to being part of collectivities and collaborative relationships through his work as an editor of the leading social and cultural theory journal, Theory, Culture and Society in the 1990s and worked as deputy director of the TCS Centre in Nottingham, later housed at Goldsmiths, where he was a professor in the former Centre for Cultural Studies, and then towards the end of his life in the Department of Media, Communications and Cultural Studies. In addition, he was both extremely modest and extremely generous as a $\mathrm{PhD}$ supervisor, journal editor, co-writer, collaborator and colleague. As a journal editor he provided insights and generous engagement with articles submitted to Theory, Culture \& Society, and Body \& Society, sharing his knowledge and helping authors develop their work in ways that have helped to shape and will continue to shape debates into the future. This includes an important intervention made in the field of affect study in a special issue on Affect published in Body \& Society (Blackman and Venn 2010). We include his own contribution to the issue as part of this special issue, which he initially started to develop in a panel discussion on affect in Tokyo at a Theory, Culture \& Society conference in 2007. The panel represented what Couze enjoyed, thrived on and was drawn to, which was collaboration, discussion, dialogue, and wanting to think with others to provide what he termed in his last book, After Capital, protocols for living. Couze always saw himself as part of collectives and with others, committed to cultivating the conditions for a commons that he could share and be part of, with his characteristic urgency and passion.

His landmark 2000 book, Occidentalism: Modernity and Subjectivity. critically addresses the becoming West of Europe and the becoming Modern of the world, demonstrating that questions of postmodernity are inseparable from post-coloniality, which he further developed in his 2005 book, The Postcolonial Challenge: towards alternative worlds, leading onto the development for TCS of the New Encyclopaedia Project, which led to Problematizing Global Knowledge (2006).

His 2014 book with Francesca Ashurst, Poverty, Inequality, Education: a political economy of school exclusion, confronts the history of the pathologisation and 
criminalisation of poverty and thus challenges the practice of exclusion by uncovering its roots in nineteenth century social and educational policy targeting poor children. This focus on inequality and poverty is also further developed in his final volume.

He became deeply concerned with the interconnecting currents producing the perfect storm in which we find ourselves today: the growth of inequality, the rise of neoliberalism, the renewed racism, the wars and the ecological crisis. In a closely argued volume, he shows how all of these are deeply interwoven, but does not stop there. It is his commitment to offer to the next generation, to those that outlive him, a vision for a possible future 'After Capital', a vision in which his protocols for living developed in the book confront war, climate change and extinction, and the vast inequalities in living, through imagining a post-capitalist, post-anthropocentric politics of the common world. Those who knew Couze will know how committed he was to what is shared and connects us-human and non-human, and to working together on collaborative projects to make a difference to our personal and political lives. Couze never shied from confronting pain, loss, precarity, racism, shared vulnerabilities, and the vast inequities in living and dying, and the need to think across the monstrous binaries and separations that prevent the analysis and formation of a genuine commons. The book represents his thinking as he faced the end of his life and looked to the future of ours. He rightly saw this book as his legacy to those of us who outlive him. In the moment of far-reaching global challenges, from climate change, to the current pandemic to the global financial situation, we would do well to pay attention to his words and to carefully attend to what, in addition, he was urgently pointing us towards in his last paper.

Publisher's Note Springer Nature remains neutral with regard to jurisdictional claims in published maps and institutional affiliations. 